\title{
Maltodextrin and dental caries: a literature review
}

\author{
Maltodextrina e cárie dentária: uma revisão de literatura
}

\author{
Gabriela REZENDE ${ }^{1}$ \\ (iD) ORCID iD 0000-0002-7347-0973 \\ Lina Naomi HASHIZUME ${ }^{1}$ \\ (i) ORCID iD 0000-0001-5477-2768
}

\begin{abstract}
Carbohydrates are largely present in our diet. Sucrose the most commonly consumed carbohydrat and presents a high cariogenic potential. Starch has low cariogenic potential but this effect may be increased if it is consumed in combination with a sucrose-rich diet due to a prolonged retention on tooth surfaces. Maltodextrin is derived from the acid hydrolysis and/or enzymatic hydrolysis of corn starch and it is increasingly present in a variety of industrialized foods such as infant formulas, sports drinks and energy supplements. Yet, its role in the development of dental caries is not clear. The objective of this study was to conduct a literature review of the association between maltodextrin and dental caries. Based on the studies included in this review it can be concluded that maltodextrin has an acidogenic potential lower than sucrose, and that there is a lack of studies about the association between maltodextrin and sucrose and it may not be possible to assess the relationship to dental caries.
\end{abstract}

Indexing terms: Carbohydrates. Dental caries. Literature.

\section{RESUMO}

Os carboidratos são amplamente presentes em nossa dieta. A sacarose é o carboidrato mais comumente consumido e apresenta um alto potencial cariogênico. O amido apresenta um baixo potencial cariogênico, mas este efeito pode ser aumentado se for consumido em combinação com uma dieta rica em sacarose, devido a uma retenção prolongada nas superfícies dos dentes. A maltodextrina é derivada a partir da hidrólise ácida e/ou enzimática do amido de milho e está cada vez mais presente em uma variedade de alimentos industrializados, como fórmulas infantis, bebidas esportivas e suplementos energéticos. Contudo, o seu papel no desenvolvimento da cárie dentária ainda não está esclarecido. O objetivo deste estudo foi realizar uma revisão da literatura sobre a associação entre a maltodextrina e a cárie dentária. Com base nos estudos incluídos nesta revisão, pode-se concluir que a maltodextrina apresenta um potencial acidogênico menor do que a sacarose, e que estudos sobre a associação entre maltodextrina e sacarose são escassos não podendo ser possível avaliar sua relação com cárie dentária.

Termos de indexação: Carboidratos. Cárie dentária. Literatura.

\section{INTRODUCTION}

Maltodextrin is a starch hydrolysate that is often used by the industry and is increasingly present in a variety of foods such as infant formulas, sports drinks, and energy supplements. Maltodextrin-based products, especially infant soy formulas, are commonly used for children who have allergies or lactose intolerance $[1,2]$. These formulas are used as cow's milk substitute and are given to children at high frequency and at night when the salivary flow is reduced, favoring the development of dental caries $[3,4]$. However, its role in the development of dental caries is not clear. Therefore, the objective of this study was to conduct a literature review regarding the association between maltodextrin and dental caries.

\section{Carbohydrates and dental caries}

Although epidemiological indicators of dental caries have shown important decline in the prevalence of this disease, it appears to be present in childhood in many countries [5-7]. Dental caries is considered a multifactorial disease and its development is strongly associated with a diet high in carbohydrates. Ingestion of high quantities of fermentable carbohydrates induces the formation of a

\footnotetext{
${ }^{1}$ Universidade Federal do Rio Grande do Sul, Faculdade de Odontologia, Departamento de Odontologia Preventiva e Social. Rua Ramiro Barcelos, 2492, 90035-003, Porto Alegre, RS, Brasil. Correspondência para / Correspondence to: G REZENDE. E mail: gabi_rezende87@yahoo.com.br.

$\mathbf{v} \mathbf{v} \mathbf{v}$

Como citar este artigo / How to cite this article

Rezende G, Hashizume LN. Maltodextrin and dental caries: a literature review. RGO, Rev Gaúch Odontol. 2018;66(3):257-262. http://dx.doi.http:// dx.doi.org/10.1590/1981-8637201800030000103288
} 
biofilm with cariogenic microorganisms [8,9].

The association between dental caries and excessive consumption of sugars is affirmed by experts at World Health Organization, who performed an assessment of the evidence in the literature relating diet and caries in 2003. They have reported an increase in the risk for development of caries that is associated with frequent intake of sugars [10]. In the recent Food Guide for the Brazilian Population, it is emphasized that excessive sugar consumption increases the risk of developing caries [11].

With the changes in eating habits and the growth in processed food industrialization, foods high in fibers and nutrients are being replaced by processed foods with an excess of fats and carbohydrates. This facilitates the development of dental caries [12]. Carbohydrate is the food group abundantly prevalent in our diet. Carbohydrates can be classified in different ways, such as by chain length (monosaccharides, disaccharides, polysaccharides) and origin [13].

Sucrose is the most commonly consumed carbohydrate and presents a greater cariogenic potential. This feature is, in part, attributable to the fact that this is the only carbohydrate that can be used as a substrate for the synthesis of soluble and insoluble extracellular polysaccharides (EPS) by dental biofilms, favoring the colonization and adherence of microorganisms to dental surfaces and increasing the porosity of the dental biofilms [14-16].

Classical studies assessing the relationship of dental caries with diet showed that there is an increase in dental caries with the increased consumption of carbohydrates. The consistency of foods and how often foods high in sugar are consumed has also a large influence [17-18].

A study conducted monitored mentally disabled adults over 5 years in order to assess the caries increment with increased sucrose intake, influence of food consistency, and frequency of sugar intake. The authors observed that there was a low incidence of caries when the diet was almost free of carbohydrates and less of a caries increment with the consumption of carbohydrates derived from starch at meals [17]. Other study with a group of children, living in an orphanage, who had a lacto-vegetarian diet with minimal amounts of sugar and refined flour observed a lower prevalence of caries. However, an increase in dental caries prevalence occurred when the children left the orphanage. They concluded that diet had extreme influence on the development of caries [18].

A recent systematic review about the association between sugar intake and dental caries, analyzed 55 studies and the authors concluded that there was consistent evidence of moderate quality supporting a relationship between the amount of sugars consumed and dental caries development [19].

The relation of sucrose and dental caries is well established in the literature. Despite the development of this disease being associated with a variety of factors, the frequency and consistency of food containing sucrose have a great influence on the development of dental caries.

\section{Starch and dental caries}

Starch is a glucose polymer composed of two polysaccharides (amylose and amylopectin) that which are found in a variety of foods such as cereals, roots, and seeds. The starch molecules are inside insoluble beads. When subjected to heating processes, they undergo a series of changes in a process called gelatinization. The products having an increased gelatinization potential are more susceptible to enzymatic breakdown, causing partial degradation to a soluble form that can be fully dissolved by salivary and bacterial amylase and be transformed into maltose, maltotriose, dextrins, and small amounts of glucose. Salivary amylase performs the hydrolysis of glycosidic chains, resulting in smaller units that are readily metabolized by the microorganisms of the oral cavity. The extent of this hydrolysis is determined by the time that food is retained in the oral cavity [20-22].

Starch has a minimal influence on dental caries if consumed in small quantities in the diet. However, this effect may be magnified if starch is consumed in combination with a diet rich in sucrose owing to its prolonged retention on tooth surfaces. The starch cariogenicity differs by food source, amount, and frequency of consumption and the method of preparation [23].

Some epidemiological and in vitro studies reported that starchy foods presents low or no cariogenic potential $[17,24,25]$. A study found a low incidence of caries in a group that consumed bread and pasta associated with reduced quantities of sugars [17]. However, it must be considered that the study had a long duration, was modified several times over the period, and that there was a marked variability among the subjects studied. In addition, there were differences in the consistency of food and the frequency in which it was offered to different study groups. 
The group receiving a higher frequency of carbohydrates with a sticky consistency between meals showed a higher caries prevalence than the group that received bread and pasta less frequently. Other study conducted for two years with 405 schoolchildren, evaluated the cariogenic potential of dietary starch and sugars. In addition, the simultaneous effect of starch with sucrose relating the cariogenic potential of sucrose with the viscosity of the starch was evaluated. The authors observed that children who had a diet with high consumption of starch and low sugar had a lower incidence of dental caries [24].

An in vitro study investigated the cariogenicity of starch and fruits by measuring the acidogenicity of the biofilm and enamel demineralization. The results indicated that all foods were less acidogenic than sucrose. All foods reached the maximum decrease in $\mathrm{pH}$ and produced enamel demineralization. The author concluded that all foods were less cariogenic than sucrose [25].

A literature review investigated the relationship between food starch and dental caries. The authors considered as determinants for starch cariogenicity the following factors: consumption intensity (quantity and frequency), exposure tooth surfaces exposure, starch bioavailability, microorganisms present in the biofilm, biofilm $\mathrm{pH}$ decrease, and salivary flow. Several experimental studies indicate that foods containing starch have a significant cariogenic potential, and studies with humans have yielded only limited information and have been inconclusive [21].

Many food products have the association between starch and sucrose in their composition. Among the carbohydrates, sucrose is considered the most cariogenic one and this feature is partly attributable to the fact that this carbohydrate is used as a substrate for the synthesis of EPS in dental biofilm $[16,26]$. In vivo studies report that the cariogenic potential of starch consumption associated with sucrose is greater than the cariogenic potential of these carbohydrates consumed by alone $[16,24,25]$ Furthermore, some studies have suggested that the addition of starch would enhance the cariogenic potential of sucrose $[27,28]$.

An experimental study was conducted with rats infected with Streptococcus mutans (SM) and Actinomyces viscosus. The animals received different diets with sucrose, starch, a mixture of sucrose and starch, or sucrose and boiled starch. As result, the authors found that the baked starch alone or in combination with sucrose was cariogenic but less than sucrose alone [27].

An in situ study evaluated the effect of starch alone or associated with sucrose on the enamel demineralization and on the dental biofilm formed. The authors evaluated the amylase activity, biofilm acidogenicity, biofilm composition, and the enamel microhardness. The results obtained showed that the greatest loss of microhardness was observed when starch was associated with sucrose. Based on these results, the authors concluded that a small amount of starch added to the sucrose results in an increase in cariogenic potential of biofilm [28].

The association between starch and sucrose may also cause microbiological and structural effects in biofilms. An in vitro study evaluated the influence of starch alone or in combination with sucrose on polyssacharides content, gene expression, and acidogenicity of SM in biofilms. The authors observed that the combination of starch with sucrose had significant effects on the composition and structure of the EPS matrix and effects on gene expression of SM. They concluded that this combination may increase the cariogenic potential of the biofilm [29].

Although there are many studies in the literature about starch and caries this relationship is not clearly established when compared with sucrose and dental caries.

\section{Starch hydrolysates}

The starch hydrolysates can be divided into maltodextrins and glucose syrups. These are generally comprised of glucose, maltose, maltotriose, and glucose polymers. The final concentration depends on the method and degree of hydrolysis of cornstarch, which is chemically defined as the "Dextrose Equivalent" (DE) of this oligosaccharide. The DE is expressed as dextrose and calculated as a percentage of total dry mass. The higher the value of the $D E$, the greater the amount of reducing sugars it will contain and the more readily the product will be metabolized by the oral bacteria. Maltodextrins are complex in nature and have a DE of less than 20 , and glucose syrups have a DE higher than 20 [13].

\section{Maltodextrin}

Maltodextrin is the most used starch hydrolysate by food industry. It is classified as an oligosaccharide and is derived from acid hydrolysis and/or enzymatic hydrolysis of cornstarch and subsequent drying. The amount of glucose and maltose is considered low in comparison to long chains of polysaccharides. Also called glucose polymer, maltodextrin can be characterized as virtually tasteless and odorless. Its composition will determine its potential as a sweetener. Its sweetness increases with increased concentrations of low molecular weight saccharides, such 
as the presence of glucose $[3,13,30,31]$. Maltodextrins are used in the food industry as thickeners in baby food, sauces, and soups. Maltodextrins have a non-sweetener role. They are used to increase the caloric content of infant formulas and dietary supplements and in some sports beverages [32-34].

Many maltodextrin-based products have sucrose in their composition and it is not known if this association has a particular effect on the cariogenic potential of these foods. Various studies in the literature have evaluated the acidogenicity of maltodextrin on biofilm, and showed that maltodextrin is less acidogenic than sucrose $[2,32,33,35-38]$.

An in vitro study evaluated the acidogenicity potential of products containing maltodextrin, glucose syrup, milk, and cow's solution used as milk replacer and, compared this with sucrose in adult volunteers. They observed that the products containing maltodextrin caused a decrease in the $\mathrm{pH}$ of the biofilm, but to less than the $\mathrm{pH}$ decrease caused by the sucrose [36].

Other in vitro study assessed the effects of artificial sweeteners and maltodextrin present in iced teas on the $\mathrm{pH}$ of dental biofilm. The different compositions of teas compared were sucralose; sucralose and maltodextrin; sucralose, maltodextrin, and dextrose; and tea containing sucrose. The authors concluded that sucrose caused the greatest decrease in $\mathrm{pH}$, either alone or combined with maltodextrin. Sucralose, maltodextrin, and dextrose exhibited a significantly lower $\mathrm{pH}$ decrease [35].

An in vivo study verified the effect of three maltodextrins with different $\mathrm{DE}$ on the $\mathrm{pH}$ decrease of biofilms of 10 volunteers, as well as the acidogenicity of drinks for children containing maltodextrin compared with sucrose and sorbitol solution. It was concluded that, although less acidogenic than sucrose, maltodextrin led to a substantial decrease in the $\mathrm{pH}$ of the biofilm and may present potential to demineralize enamel [31].

A study evaluated the effect of infant milk formulas composed of different sugars and the effects on dental biofilm $\mathrm{pH}$. Six formulas were tested: three contained maltodextrin associated with sucrose, two contained lactose, and one contained only sucrose. The formulations containing sucrose in combination with other carbohydrates such as maltodextrin showed a greater decrease in the $\mathrm{pH}$ than formulas containing lactose [2].

Other study evaluate the $\mathrm{pH}$ of the biofilm after rinsing with regular infant formulas, soy formula (containing maltodextrin), bovine milk, water, and sucrose solution. The sucrose solution showed the largest decrease in $\mathrm{pH}$, being more acidogenic. However, among the tested formulas the soy formula containing maltodextrin showed the largest decrease in $\mathrm{pH}$, presenting itself as more acidogenic, similar to sucrose [36].

Few studies evaluated the effects of the association of maltodextrin and sucrose $[4,37]$.

An in vitro study investigated the effect of the association of maltodextrin and sucrose on the acidogenic and adherence profiles of cariogenic bacteria. The authors observed that when the microorganism was SM, maltodextrin-sucrose mixture presented a high acidogenic potential and high microbial adherence similar to sucrose alone. The authors concluded that the addition of maltodextrin to sucrose does not increase the cariogenicity of sucrose in terms of acidogenicity and adherence of the cariogenic bacteria [37].

Other in situ study verified the effects of milk and soy-based infant formulas associated or not to sucrose on enamel demineralization and on biofilm composition. Both infant formulas, special for babies, contained a small percentage of maltodextrin. After the analysis of mineral loss and the biochemical and microbiological composition of the biofilm, the authors concluded that milk-based and soy-based infant formula presents a potential to induce demineralization in deciduous enamel; this potential increased when sweetened with sucrose [4].

\section{DISCUSSION}

The present review observed that most studies were performed with maltodextrin alone or comparing the different maltodextrin DE. Fewer studies evaluated the association between maltodextrin and other sugars. Moreover, the studies use different evaluation parameters, making difficult the comparison between the results. The in vivo studies were mostly limited to evaluation of maltodextrin acidogenicity in biofilm and showed that maltodextrin has an acidogenic potential but lower than sucrose. Only one in situ study evaluating the combination of maltodextrin with sucrose showed that maltodextrin cariogenic potential increases when it is associated with sucrose [2]. However, the study was developed from deciduous dental enamel, which has a different mineral structure from permanent enamel. Deciduous enamel has lower levels of calcium and phosphorus, a smaller thickness, and a higher density of enamel prisms compared with permanent enamel [39]. Therefore, the results cannot be generalized to permanent enamel. No studies, 
evaluated the cariogenicity of maltodextrin on dentin, were found in the literature. Therefore, it is suggested that further studies may be conducted to assess the cariogenic potential of maltodextrin alone and in association with other carbohydrates on permanent enamel and dentin.

\section{FINAL CONSIDERATIONS}

Based on the studies included in this review, it can be concluded that maltodextrin has an acidogenic

\section{REFERENCES}

1. Consenso Brasileiro sobre Alergia Alimentar. Rev Bras Alerg Imunopatol 2007;31(2):79-85.

2. Raju AS, Hirehal M, Manjunath PG, Reddy VV, Natraj CG. The acidogenic potential of diferent milk formulas on dental plaque pH. Oral Health Prev Dent. 2012;10(3):225-30. doi: 10.3290/j. ohpd.a28518

3. Kearsley MW, Sicard PJ. The chemistry of starches and sugars present in food. In: Dietary starches and sugars in man: A comparison. London: Springer; 1989. p. 1-34.

4. de Mazer Papa AM, Tabchoury CP, Del Bel Cury AA, Tenuta LM, Arthur RA, Cury JA. Effect of milk and soy-based infant formulas on in situ demineralization of human primary enamel. Pediatr Dent. 2010;32(1):35-40.

5. Kaste LM, Gift HC. Inappropriate infant bottle feeding. Status of the Healthy People 2000 objective. Arch Pediatr Adolesc Med. 1995;149(7):786-91. doi: 10.1001/ archpedi.1995.02170200076012

6. Tinanoff N, O'Sullivan DM. Early childhood caries: overview and recent findings. Pediatr Dent. 1997;19(1):12-6.

7. Schroth RJ, Cheba V. Determining the prevalence and risk factors for early childhood caries in a community dental health clinic. Pediatr Dent. 2007;29(5):387-96.

8. Paes Leme AF, Koo H, Bellato CM, Bedi G, Cury JA. The role of sucrose in cariogenic dental biofilm formation: new insight. J Dent Res. 2006;85(10):878-87. doi: 10.1177/154405910608501002

9. Van Houte J, Russo J, Prostak KS. Increased pH-lowering ability os Streptococcus mutans cell masses associated with extracelular glucan rich matrix material and the mechanisms involved. J Dent Res. 1989;38(3):451-59. doi: $10.1177 / 00220345890680030301$

10. WHO. The World Health Organization. The World Oral Health Report 2003. Geneva: World Health Organization; 2003.

11. Brasil. Ministério da Saúde. Secretaria de Atenção à Saúde. Departamento de Atenção Básica. Guia alimentar para a população brasileira. 2a ed. Brasília: Ministério da Saúde; 2014 [citado 2017 Nov 10]. Disponível em: <http://bvsms.saude.gov. br/bvs/publicacoes/guia_alimentar_populacao_brasileira_2ed. $\mathrm{pdf}>$. potential lower than sucrose. However, studies, reporting the cariogenic potential of maltodextrin and its association with others carbohydrates, are scarce in the literature.

\section{Collaborators}

G REZENDE, selection of articles and writing of manuscript, LN HASHIZUME, design of research project, planning of steps, analysis and interpretation of results, writing of the manuscript.

12. Mateos A. Brasileiros comem cada vez mais e com pior qualidade. Rev APCD. 1999;53(1):8-20

13. Moynihan PJ. Update on the nomenclature of carbohydrates and their dental effects. J Dent. 1998;26(3):209-18. doi: 10.1016/ S0300-5712(97)00010-9

14. Rölla G, Scheie AA, Ciardi JE. Role of sucrose in plaque formation. Scand J Dent Res. 1985;93(2):105-11. doi: 10.1111/ j.1600-0722

15. Dibdin GH, Shellis RP. Psical and biochemical studies of Streptococcus mutans sediments suggest new fhyactors linking the cariogenicity of plaque with its extracellular polysaccharide content. J Dent Res. 1988;67(6):890-95. doi: $10.1177 / 00220345880670060101$

16. Bowen $\mathrm{WH}$. Do we need to be concerned about dental caries in the coming millennium? Crit Rev Oral Biol Med. 2002;13(2):12631. doi: $10.1177 / 154411130201300203$

17. Gustafsson BE, Quensel CE, Lanke LS, et al. The vipeholm dental caries study. The effects of different levels of carbohydrate intake in 436 individuals observed for five years. Acta Odontol Scand. 1954;11(3-4):232-364. doi: 10.3109/00016355308993925

18. Harris R. Biology of the children of Hopewood House, Bowral, Australia. 4. Observations of dental caries experience extending over five years (1957-1961). Aus Dent J. 1963;8(6):521-28. doi: 10.1111/j.1834-7819.1967.tb04263.x

19. Moynihan PJ, Kelly SAM. Effect on caries of restricting sugars intake: systematic review to Inform WHO guidelines. J Dent Res. 2014;93(1):8-18. doi: 10.1177/0022034513508954

20. Winter GB, Rule DC, Mailer GP, James PM, Gordon PH. The prevalence of dental caries in pre-school children aged 1 to 4 years. $\mathrm{Br}$ Dent J. 1971;130(10):271-7.

21. Lingström $P$, van Houte J, Kashket $S$. Food starches and dental caries. Crit Rev Oral Biol Med. 2000;11(3):366-380. doi: $10.1177 / 10454411000110030601$

22. Lingström P, Birkhed D, Granfeldt Y, Björck I. Ph measurements of human dental plaque after consumption of starchy foods using the microtouchand the sampling method. Caries Res. 1993;27:394-401. doi: 10.1159/000261570

23. Fejerskov O, Kidd E. Dental caries: the disease and its clinical management. $2^{\text {a }}$ ed. Oxford: Blackwell Munksgaard; 2008.

24. Rugg-Gunn AJ, Hackett AF, Appleton DR. Relative cariogenicity 
of starch and sugars in a two-year longitudinal study of 405 English schoolchildren. Caries Res. 1987;21(5):464-73. doi: 10.1159/000261053

25. Firestone AR, Shmid R, Muhlemann HR. Cariogenic effects of cooked wheat starch alone or with sucrose and frequencycontrolled feedings in rats. Arch Oral Biol. 1982;27(9):759-63. doi:10.1016/0003-9969(82)90026-7.

26. Paes Leme AF, Koo $H$, Bellato $C M$, Bedi G, Cury JA. The role of sucrose in cariogenic dental biofilm formation: new insight. J Dent Res. 2006;85(10):878-87. doi: 10.1177/154405910608501002

27. Thurnheer T, Giertsen E, Gmür R, Guggenheim B. Cariogenicity of soluble starch in oral in vitro biofilm and experimental rat caries studies: a comparison. J Appl Microbiol. 2008;105(3):829-36. doi: 10.1111/j.1365-2672.2008.03810.x

28. Ribeiro CCC, Tabchoury CPM, Del Bel Cury AA, Tenuta LMA, Rosalen PL, Cury JA. Effect of starch on the cariogenic potential of sucrose. Br J Nutr. 2005;94(1):44-50. doi: 10.1079/ BJN20051452

29. Duarte $\mathrm{S}$, Klein Ml, Aires $\mathrm{CP}$, Cury JA, Bowen $\mathrm{WH}$, Koo H. Influences of starch and sucrose on Streptococcus mutans biofilms. Oral Microbiol Immunol. 2008;23(3):206-12. doi: 10.1111/j.1399-302X.2007.00412.x

30. Moynihan PJ, Gould ME, Huntley N, Thorman S. Effect of glucose polymers in water, milk and a milk substitute on plaque $\mathrm{pH}$ in vitro. Int J Paediatr Dent. 1996;6(1):19-24. doi: 10.1111/j.1365-263X.1996.tb00203.x

31. Al-Khatib G, Duggal M, Toumba KJ. An evaluation of the acidogenic potential of maltodextrins in vivo. J Dent. 2001; 29 (6): 409-14. doi: 10.1016/\$0300-5712(01)00034-3

32. Moynihan PJ, Wright WG, Walton AG. A comparison of the relative acidogenic potential of infant milk and soya infant formula: a plaque pH study. Int J Paediatr Dent. 1996;6(3):17781. doi: 10.1111/j.1365-263X.1996.tb00238.x
33. Levine RS. Briefing paper: Maltodextrins and caries. Br J Nutr. 1998;185(8):392.

34. Grenby TH, Mistry M. Properties of maltodextrins and glucose syrups in experiments in vitro and in the diets of laboratory animals, relating to dental health. Br J Nutr. 2000;84(4): 56574. doi: $10.1017 /$ S0007114500001884

35. Meyerowitz C, Syrrakou EP, Raubertas RF. Effect of sucralosealone or bulked with maltodextrin and/or dextrose- on plaque $\mathrm{pH}$ in humans. Caries Res. 1996;30(6):439-44. doi: $10.1159 / 000262357$

36. Bhat SS, Dubey A. Acidogenic potential of soya infant formula in comparison with regular infant formula and bovine milk: a plaque pH study. J Indian Soc Pedod Prev Dent. 2003;21(1):304.

37. Stegues CG, Arthur RA, Hashizume LN. Effect of the association of maltodextrin and sucrose on the acidogenicity and adherence of cariogenic bacteria. Arch Oral Biol. 2016; 65:72-6. doi: 10.1016/j.archoralbio.2016.01.018

38. Dashper SG, Saion BN, Stacey MA, et al. Acidogenic potential of soy and bovine milk beverages. J Dent. 2012;40(9):736-41. doi: 10.1016/j.jdent.2012.05.004

39. De Menezes Oliveira MA, Torres CP, Gomes-Silva JM, Chinelatti MA, De Menezes FC, Palma-Dibb RG, et al. Microstructure and mineral composition of dental enamel of permanent and deciduous teeth. Microsc Res Tech. 2010;73(5):572-7. doi: 10.1002/jemt.20796 